\title{
Immunological stress in kidney cancer patients undergoing either open nephrectomy or nephron-sparing surgery: An immunophenotypic study of lymphocyte subpopulations and circulating dendritic cells
}

\author{
CAMILLO PORTA ${ }^{1,2}$, LUCIA BONOMI ${ }^{1}$, BEATRICE LILLAZ ${ }^{3,6}$, CATHERINE KLERSY ${ }^{4}$, \\ ILARIA IMARISIO $^{1}$, CHIARA PAGLINO ${ }^{1}$, BIANCA ROVATI ${ }^{5}$, MARCO DANOVA ${ }^{1,5}$, \\ ELISA FERRARIS $^{1}$, MARIO MENSI ${ }^{3,7}$ and BRUNO ROVERETO ${ }^{3}$ \\ ${ }^{1}$ Medical Oncology, ${ }^{2}$ Laboratory of Pre-Clinical Oncology and Developmental Therapeutics, \\ ${ }^{3}$ Urology, ${ }^{4}$ Service of Biometry and Clinical Epidemiology, ${ }^{5}$ Laboratory of Cytometry and \\ Cellular Therapies, I.R.C.C.S. San Matteo University Hospital Foundation, I-27100 Pavia, Italy
}

Received April 22, 2008; Accepted July 10, 2008

DOI: 10.3892/or_00000173

\begin{abstract}
Immunosuppression is a characteristic hallmark of renal cell carcinoma (RCC), with several complex immune defects, almost solely at the level of cell-mediated immune function, well evident even in patients at first diagnosis. The main circulating lymphocyte subsets and the total number of circulating dendritic cells were quantified in $47 \mathrm{RCC}$ patients at diagnosis (T0), $12 \mathrm{~h}$ (T1), $24 \mathrm{~h}$ (T2) and 8 days following either radical nephrectomy or nephron-sparing surgery using flow cytometry. RCC patients presented, at baseline, (T0) a profound state of immunosuppression involving naïve T-cells, memory T-cells, CD $16^{+} \mathrm{NK}$ and total circulating dendritic cells, that worsened after 12 (T1) and $24 \mathrm{~h}$ (T2) from surgery, involving the majority of the analysed subsets; after 8 days (T3) from surgical removal of tumor, however, there was a return of all the analyzed parameters to the basal state. In conclusion, surgery causes transient but relevant immune suppression in RCC patients; even though, by day +8 , this tends to return to baseline, immunostimulatory therapies could be considered in the peri-operative setting with the aim of reducing immunosuppression and, hopefully, also disease recurrence.
\end{abstract}

Correspondence to: Dr Camillo Porta, Medical Oncology and Laboratory of Pre-Clinical Oncology and Developmental Therapeutics, I.R.C.C.S. San Matteo University Hospital Foundation, Piazzale C. Golgi, I-27100 Pavia, Italy

E-mail: c.porta@smatteo.pv.it

Present addresses: ${ }^{6}$ Division of Urology, Regional Hospital, Aosta; ${ }^{7}$ Division of Urology, Civic Hospital, Voghera, Italy

Key words: renal cell carcinoma, surgery, immunosuppression, lymphocyte subpopulations, dendritic cells

\section{Introduction}

Immunosuppression is a characteristic hallmark of cancer, and of renal cell carcinoma (RCC) in particular. We have already demonstrated (1) the presence of several complex immune defects, almost solely at the level of cell-mediated immune function, in RCC patients at first diagnosis, even in patients without disseminated disease. Furthermore, several experimental studies clearly demonstrated that renal carcinoma cells may produce soluble immunosuppressive mediators (2) as well as suppress T-cell response through different mechanisms, such as induction of $\mathrm{T}$ cell apoptosis (2), decrease in IL-2 production by $\mathrm{CD}^{+}{ }^{+}$helper T-cells, inhibition of the activity of Jak-3 kinase involved in trasduction of the signal from IL-2 receptor activation (3), and decreased activation of the nuclear factor NFK-B in the lymphocytes effecting the immune response, resulting in increased susceptibility to apoptosis (4). Other immunosuppressive factors secreted by RCC cells include IL-10 (5), which is thought to minimize a T-helper 1 response and to skew the immune response toward a type 2 response, even though this cytokine could act differently in different experimental models (6).

Animal studies, as well as our everyday clinical practice, suggest that cancer immunotherapy efficacy is inversely proportional to tumor burden. Thus, at least theoretically, the surgical removal of primary tumor could revert such immunosuppressive status; this could, at least in part, explain why, differently from other cancer types, surgical removal of the primary kidney lesion has an impact on patients' overall survival even in the presence of a synchronous metastatic disease $(7,8)$.

Only few studies have evaluated the immunological consequences of tumor resection in either mice $(9,10)$ or humans $(11,12)$. The authors found different levels of immunosuppression, which showed partial recovery after tumor removal. Danna et al (9) compared immune responses in 
mice without tumor versus mice with intact primary tumors versus mice whose primary tumors had been removed, but who already had established, spontaneous metastatic disease; in their study, the authors demonstrated that although tumorbearing animals had reduced B- and T-cell responses, the immunosuppression was reversed following primary tumor removal, even when metastatic disease was present.

In this study, we investigated the evolution of immune system in RCC patients after radical surgery (nefrectomy or nephron-sparing surgery).

\section{Patients and methods}

Patients. Thirty-nine consecutive RCC patients at first diagnosis were enrolled in this study, after giving their informed consent according to institutional requirements. They were 25 men $(64.10 \%)$ and 14 women $(45.90 \%)$, with an average age of 62.3 years (median, 63 years; range, 34-85 years). The predominant tumor histotype was clear cell renal carcinoma (29 patients, $74.36 \%$ ), while other subjects had papillary, chromophobic and sarcomatoid lesions. Most patients $(n=13,33.33 \%)$ had a moderately differentiated, Furhman's grade 2, lesion. Most patients had an early stage lesion (pT1 according to Robson's criteria in $64.09 \%$ of cases).

Patients underwent either open radical nephrectomy $(\mathrm{n}=27$, $62.23 \%)$ or nephron-sparing surgery $(n=12,30.77 \%)$; locoregional lymphadenectomy was hardly ever performed: given the low risk of recurrence in small lesions and the lack of any adjuvant treatment to decrease this risk, in Italy lymphadenectomy is often not performed in the absence of macroscopically suspicious lymph nodes. Only 7 patients $(17.95 \%)$ had an advanced lesion, with distant metastases at the time of diagnosis. None of the patients had received anticancer treatments or even immunsuppressants (including steroids) at the time of analysis. The characteristics of the patients enrolled into this study are reported in Table I.

Lymphocyte immunophenotyping. A peripheral blood sample ( $3 \mathrm{ml}$ ) was taken by venipuncture, in EDTA-containing vials. Samples were then lysed using a commercial kit (Immunoprep reagent system, Coulter Co., Miami, FL, USA) with 3 different reagents: one, containing formic acid $(1.2 \mathrm{ml} / \mathrm{l})$ for red blood cell lysis (immunoprep A); one, containing sodium carbonate $(31.3 \mathrm{~g} / 1)$ for white blood cells stabilization (immunoprep B); and one, containing paraformaldehyde (10 g/l) and buffers, for cell membrane fixation (immunoprep C). IgG1, IgG2a, FITC and PE histotype controls were provided by Coulter Co.; the characteristics of the monoclonal antibodies used to identify the studied subsets are listed in Table II.

Samples were analyzed by means of an EPICS-XL cytometer (Coulter Co.); 4 parameters were acquired and saved in list mode: 2 on a linear scale (forward scatter, FS, and side angle scatter, SS) and 2 on a logarithmic scale, fluorescence 1 (FL1-FITC) and fluorescence 2 (FL2-PE). The acquisition gate was set by determining a bitmap on the FS vs. SS cytogram delimiting the lymphocyte area; 5000 events were calculated on that population. Histotype control reading allowed calipers to be positioned to discriminate positive from negative events and to correctly compensate for fluorescence.
Table I. Patient characteristics.

\begin{tabular}{|c|c|c|}
\hline \multicolumn{3}{|l|}{ Gender } \\
\hline Male & 25 & $(64.10 \%)$ \\
\hline Female & 14 & $(35.90 \%)$ \\
\hline \multicolumn{3}{|l|}{ Age } \\
\hline$\leq 40$ & 2 & $(5.13 \%)$ \\
\hline$>40$ & 37 & $(94.87 \%)$ \\
\hline \multicolumn{3}{|l|}{ Histology } \\
\hline Clear cell carcinoma & 29 & $(74.36 \%)$ \\
\hline Papillary carcinoma & 5 & $(12.82 \%)$ \\
\hline Chromophobic carcinoma & 4 & $(10.26 \%)$ \\
\hline Sarcomatoid carcinoma ${ }^{a}$ & 1 & $(2.56 \%)$ \\
\hline \multicolumn{3}{|l|}{ Staging $(\mathrm{T})$} \\
\hline pT1a & 14 & $(35.88 \%)$ \\
\hline pT1b & 11 & $(28.21 \%)$ \\
\hline pT2 & 6 & $(15.38 \%)$ \\
\hline pT3a & 5 & $(12.82 \%)$ \\
\hline pT3b & 1 & $(2.57 \%)$ \\
\hline pT3c & 0 & $(0 \%)$ \\
\hline pT4 & 2 & $(5.14 \%)$ \\
\hline \multicolumn{3}{|l|}{ Staging $(\mathrm{N})$} \\
\hline $\mathrm{N}-$ & 3 & $(7.7 \%)$ \\
\hline $\mathrm{N}^{+}$ & 0 & $(0 \%)$ \\
\hline Nx (nodal status not assessed) & 36 & $(92.3 \%)$ \\
\hline \multicolumn{3}{|l|}{ Staging (M) } \\
\hline $\mathbf{M}^{-}$ & 32 & $(82.05 \%)$ \\
\hline $\mathrm{M}^{+}$ & 7 & $(17.95 \%)$ \\
\hline \multicolumn{3}{|l|}{ Surgery } \\
\hline Nephron-sparing surgery & 12 & $(30.77 \%)$ \\
\hline Nephrectomy & 27 & $(62.23 \%)$ \\
\hline
\end{tabular}

andependently from the WHO histotype, $>25 \%$ of the whole cell population should be sarcomatoid.

Finally, the percentage values of the studied subsets obtained by cytometric reading were converted into absolute values according to white blood cells and whole blood count values.

Evaluation of circulating dendritic cells in peripheral blood. Peripheral blood samples, collected in heparinized vials, were diluted 1:1 with RPMI-1640 supplemented with L-glutamine (Sigma Chemicals, St. Louis, MO, USA) and then layered on a Ficoll-Paque concentration gradient (density $1.077 \mathrm{~g} / 1$, Amersham Biosciences, Uppsala, Sweden) at a 1:1 ratio, and centrifuged at $2000 \mathrm{rpm}$ for $20 \mathrm{~min}$; the ring of mononuclear cells (PBMC) thus obtained was washed 3 times in a PBS buffer (Sigma Chemicals) and then centrifuged again at $1400 \mathrm{rpm}$ for $10 \mathrm{~min}$. Cells were finally resuspended in $1 \mathrm{ml}$ PBS and counted with a Bürker chamber.

Dendritic cells were sought by direct immunofluorescence with 2- and 3-color cytofluorimetic analysis, starting from 
Table II. The monoclonal antibodies used to identify each of the studied lymphocytic subset.

\begin{tabular}{|c|c|c|c|}
\hline Subset & Fluorochrome & Clone & Function \\
\hline CD4 & FITC-PE & $\mathrm{T} 4$ & T-helper lymphocyte \\
\hline CD3 & $\mathrm{PE}$ & $\mathrm{T} 3$ & Mature T-cells, TCR complex \\
\hline CD8 & FITC & $\mathrm{T} 8$ & T-cytotoxic lymphocyte \\
\hline CD3/HLA-DR & $\begin{array}{l}\text { PE } \\
\text { FITC }\end{array}$ & $\begin{array}{l}\mathrm{T} 3 \\
\mathrm{I} 2\end{array}$ & Activated T-lymphocytes \\
\hline $\mathrm{CD} 2$ & $\mathrm{PE}$ & $\mathrm{T} 11$ & Pan T \\
\hline $\mathrm{CD} 2 / \mathrm{CD} 25$ & $\begin{array}{l}\text { FITC } \\
\text { PE }\end{array}$ & $\begin{array}{l}\text { T11 } \\
\text { B1.49.9 }\end{array}$ & Activated T-lymphocytes \\
\hline CD56 & $\mathrm{PE}$ & NKH1 & NK-cells \\
\hline CD16 & $\mathrm{PE}$ & $3 \mathrm{G} 8$ & NK-cells \\
\hline CD16/CD56 & $\begin{array}{l}\mathrm{PE} \\
\mathrm{PE}\end{array}$ & $\begin{array}{l}\text { 3G8 } \\
\text { NKH1 }\end{array}$ & NK-cells \\
\hline $\mathrm{CD} 20$ & FITC & B1 & Pan B \\
\hline CD19 & $\mathrm{PE}$ & B4 & Pan B \\
\hline $\mathrm{CD} 4 / \mathrm{CD} 45 \mathrm{RA}$ & $\begin{array}{l}\text { FITC/PE } \\
\mathrm{PE}\end{array}$ & $\begin{array}{l}\mathrm{T} 4 \\
2 \mathrm{H} 4\end{array}$ & Nä̈ve T-cells \\
\hline $\mathrm{CD} 4 / \mathrm{CD} 45 \mathrm{RO}$ & $\begin{array}{l}\text { FITC/PE } \\
\text { FITC }\end{array}$ & $\begin{array}{l}\text { T4 } \\
\text { UCHLI }\end{array}$ & Memory T-cells \\
\hline $\mathrm{CD} 4 / \mathrm{CD} 8$ & $\begin{array}{l}\text { FITC/PE } \\
\text { FITC }\end{array}$ & $\begin{array}{l}\mathrm{T} 4 \\
\mathrm{~T} 8\end{array}$ & Immature, not yet committed, lymphocytes \\
\hline CD20/CD38 & $\begin{array}{l}\text { FITC } \\
\text { PE }\end{array}$ & $\begin{array}{l}\text { B1 } \\
\text { Leu17 }\end{array}$ & Early B-cells \\
\hline
\end{tabular}

Table III. The monoclonal antibodies used for phenotyping of circulating dendritic cells and their DC1 and DC2 subsets.

\begin{tabular}{llll}
\hline Subset & Fluorochrome & Clone & \\
\hline CD3 & FITC & T3 & Function \\
CD19 & FITC & B4 & Mature T-cells, TCR complex \\
CD20 & FITC & B1 & Pan-B \\
CD16 & FITC & $3 \mathrm{G} 8$ & Pan-B \\
CD56 & FITC & T11 & NK-cells \\
CD11b & FITC & Bear1 & Pan T \\
CD14 & FITC & Mo2 & Granulocytes, monocytes, NK-cells \\
CD34 & FITC & 588 & Monocytes \\
HLA-DR & PC5 & HLA-DR & HLA-DR locus \\
CD11c & PE & BU15 & Granulocytes, monocytes, NK-cells T and B subsets \\
CDw123 & PE & 9 F5 & $\alpha$ chain of IL-3R \\
\hline
\end{tabular}

PBMC. One million cells were incubated for 20 min at $4^{\circ} \mathrm{C}$ with a cocktail of lineage-specific antibodies conjugated with FITC, that is CD3, CD19, CD20, CD11b, CD56, CD16, CD34, CD14 and HLA-DR PC5. At the end of incubation, the cells, washed twice in a PBS buffer and centrifuged at $1400 \mathrm{rpm}$ for $10 \mathrm{~min}$, were ready for cytometric reading. The cocktail above marked T-, B- and NK cells, macrophages, granulocytes-monocytes and hematopoietic precursors 
Table IV. Summary of the immune dysfunctions evidenced at the different time-points. ${ }^{\text {a }}$

\begin{tabular}{|c|c|c|c|c|c|c|c|}
\hline Subpopulations & & T0 & $\mathrm{T} 1$ & $\mathrm{~T} 2$ & $\mathrm{~T} 3$ & $\begin{array}{l}\text { Changes over } \\
\text { time } \\
\text { overall p-value }\end{array}$ & $\begin{array}{c}\text { Post-hoc } \\
\text { comparisons } \\
\text { p-value }\end{array}$ \\
\hline \multirow[t]{3}{*}{ CD8 } & Median & 403 & 219 & 271 & 369.5 & $<0.001$ & $\mathrm{~T} 0-\mathrm{T} 1=0.000$ \\
\hline & 25 th & 270 & 146 & 178 & 228.5 & & $\mathrm{~T} 0-\mathrm{T} 2=0.000$ \\
\hline & 75 th & 593 & 331 & 389 & 578 & & $\mathrm{~T} 0-\mathrm{T} 3=0.511$ \\
\hline \multirow[t]{3}{*}{ CD4 } & Median & 647 & 383 & 483 & 653 & $<0.001$ & $\mathrm{~T} 0-\mathrm{T} 1=0.000$ \\
\hline & 25 th & 496 & 298 & 323 & 461.5 & & $\mathrm{~T} 0-\mathrm{T} 2=0.000$ \\
\hline & 75 th & 1039 & 485 & 642 & 804 & & $\mathrm{~T} 0-\mathrm{T} 3=0.035$ \\
\hline \multirow[t]{3}{*}{ CD3 } & Median & 1046 & 548 & 728.5 & 968.5 & $<0.001$ & $\mathrm{~T} 0-\mathrm{T} 1=0.000$ \\
\hline & 25 th & 791 & 459 & 507 & 790.5 & & $\mathrm{~T} 0-\mathrm{T} 2=0.000$ \\
\hline & 75 th & 1352 & 730 & 877 & 1072 & & $\mathrm{~T} 0-\mathrm{T} 3=0.05$ \\
\hline \multirow[t]{3}{*}{ CD3/HLA-DR } & Median & 22 & 15 & 14.5 & 25 & $<0.001$ & $\mathrm{~T} 0-\mathrm{T} 1=0.002$ \\
\hline & 25 th & 14 & 8 & 8 & 13 & & $\mathrm{~T} 0-\mathrm{T} 2=0.000$ \\
\hline & 75 th & 35 & 22 & 25 & 43.5 & & $\mathrm{~T} 0-\mathrm{T} 3=0.156$ \\
\hline \multirow[t]{3}{*}{ CD2 } & Median & 1204 & 676 & 827.5 & 1107.5 & $<0.001$ & $\mathrm{~T} 0-\mathrm{T} 1=0.000$ \\
\hline & 25 th & 926 & 556 & 697 & 890 & & $\mathrm{~T} 0-\mathrm{T} 2=0.000$ \\
\hline & 75 th & 1610 & 817 & 1001 & 1242.5 & & $\mathrm{~T} 0-\mathrm{T} 3=0.033$ \\
\hline \multirow[t]{3}{*}{$\mathrm{CD} 2 / \mathrm{CD} 25$} & Median & 5 & 3 & 4 & 4.5 & 0.042 & $\mathrm{~T} 0-\mathrm{T} 1=0.019$ \\
\hline & 25 th & 2 & 1 & 2 & 3 & & $\mathrm{~T} 0-\mathrm{T} 2=0.147$ \\
\hline & 75 th & 10 & 6 & 7 & 10 & & T0-T3=0.909 \\
\hline \multirow[t]{3}{*}{ CD56 } & Median & 90 & 45 & 26 & 57 & $<0.001$ & $\mathrm{~T} 0-\mathrm{T} 1=0.006$ \\
\hline & 25 th & 22 & 8 & 11 & 31 & & $\mathrm{~T} 0-\mathrm{T} 2=0.002$ \\
\hline & 75 th & 153 & 107 & 80 & 220.5 & & $\mathrm{~T} 0-\mathrm{T} 3=0.389$ \\
\hline \multirow[t]{3}{*}{ CD16 } & Median & 139 & 67 & 72 & 106 & $<0.001$ & $\mathrm{~T} 0-\mathrm{T} 1=0.000$ \\
\hline & 25 th & 76 & 34 & 34 & 45 & & $\mathrm{~T} 0-\mathrm{T} 2=0.000$ \\
\hline & 75 th & 215 & 165 & 118 & 197 & & $\mathrm{~T} 0-\mathrm{T} 3=0.233$ \\
\hline \multirow[t]{3}{*}{ CD16/CD56 } & Median & 37 & 14 & 3 & 13.5 & $<0.001$ & $\mathrm{~T} 0-\mathrm{T} 1=0.082$ \\
\hline & 25 th & 3 & 1 & 1 & 3.5 & & $\mathrm{~T} 0-\mathrm{T} 2=0.007$ \\
\hline & 75 th & 68 & 44 & 36 & 87 & & $\mathrm{~T} 0-\mathrm{T} 3=0.000$ \\
\hline \multirow[t]{3}{*}{$\mathrm{CD} 20$} & Median & 158 & 114 & 130 & 150.5 & $<0.001$ & $\mathrm{~T} 0-\mathrm{T} 1=0.002$ \\
\hline & 25 th & 96 & 67 & 105 & 95 & & $\mathrm{~T} 0-\mathrm{T} 2=0.711$ \\
\hline & 75 th & 239 & 161 & 198 & 198 & & $\mathrm{~T} 0-\mathrm{T} 3=0.870$ \\
\hline \multirow[t]{3}{*}{ CD19 } & Median & 154 & 118 & 115 & 144 & 0.438 & $\mathrm{~T} 0-\mathrm{T} 1=0.443$ \\
\hline & 25 th & 90 & 55 & 80 & 81 & & $\mathrm{~T} 0-\mathrm{T} 2=0.901$ \\
\hline & 75 th & 190 & 168 & 189 & 187.5 & & $\mathrm{~T} 0-\mathrm{T} 3=0.347$ \\
\hline CD4/CD45RA & Median & 187 & 99 & 109 & 156 & $<0.001$ & $\mathrm{~T} 0-\mathrm{T} 1=0.001$ \\
\hline \multirow[t]{2}{*}{ T naive } & 25 th & 90 & 58 & 61 & 100 & & $\mathrm{~T} 0-\mathrm{T} 2=0.002$ \\
\hline & 75 th & 286 & 145 & 173 & 231.5 & & $\mathrm{~T} 0-\mathrm{T} 3=0.683$ \\
\hline $\mathrm{CD} 4 / \mathrm{CD} 45 \mathrm{RO}$ & Median & 181 & 105 & 157.5 & 196.5 & $<0.001$ & $\mathrm{~T} 0-\mathrm{T} 1=0.000$ \\
\hline \multirow[t]{2}{*}{ T memory } & 25 th & 98 & 57 & 71 & 98.5 & & $\mathrm{~T} 0-\mathrm{T} 2=0.006$ \\
\hline & 75 th & 356 & 214 & 284 & 302.5 & & $\mathrm{~T} 0-\mathrm{T} 3=0.447$ \\
\hline \multirow[t]{3}{*}{$\mathrm{CD} 4 / \mathrm{CD} 8$} & Median & 10 & 5 & 7 & 7 & 0.355 & $\mathrm{~T} 0-\mathrm{T} 1=0.111$ \\
\hline & 25 th & 5 & 3 & 3 & 3.5 & & $\mathrm{~T} 0-\mathrm{T} 2=0.493$ \\
\hline & 75 th & 20 & 10 & 12 & 14 & & $\mathrm{~T} 0-\mathrm{T} 3=0.161$ \\
\hline
\end{tabular}


Table IV. Continued.

\begin{tabular}{|c|c|c|c|c|c|c|c|}
\hline Subpopulations & & T0 & $\mathrm{T} 1$ & $\mathrm{~T} 2$ & $\mathrm{~T} 3$ & $\begin{array}{l}\text { Changes over } \\
\text { time } \\
\text { overall p-value }\end{array}$ & $\begin{array}{c}\text { Post-hoc } \\
\text { comparisons } \\
\text { p-value }^{b}\end{array}$ \\
\hline \multirow{3}{*}{ CD20/CD38 } & Median & 10 & 10 & 9.5 & 8 & 0.680 & $\mathrm{~T} 0-\mathrm{T} 1=0.854$ \\
\hline & 25 th & 6 & 4 & 5 & 3.5 & & $\mathrm{~T} 0-\mathrm{T} 2=0.703$ \\
\hline & 75 th & 21 & 14 & 20 & 14.5 & & $\mathrm{~T} 0-\mathrm{T} 3=0.253$ \\
\hline \multirow[t]{3}{*}{$\mathrm{DC}$} & Median & 0.58 & 0.45 & 0.39 & 0.75 & 0.126 & $\mathrm{~T} 0-\mathrm{T} 1=0.404$ \\
\hline & 25 th & 0.38 & 0.26 & 0.24 & 0.2 & & $\mathrm{~T} 0-\mathrm{T} 2=0.041$ \\
\hline & 75 th & 0.79 & 0.80 & 0.63 & 0.91 & & $\mathrm{~T} 0-\mathrm{T} 3=0.736$ \\
\hline \multirow[t]{3}{*}{ DC 1} & Median & 39.5 & 42.6 & 39.65 & 18.25 & 0.012 & $\mathrm{~T} 0-\mathrm{T} 1=0.863$ \\
\hline & 25 th & 18.8 & 23.3 & 22 & 9.63 & & $\mathrm{~T} 0-\mathrm{T} 2=0.473$ \\
\hline & 75 th & 46.9 & 68.3 & 62.2 & 25 & & $\mathrm{~T} 0-\mathrm{T} 3=0.002$ \\
\hline \multirow[t]{3}{*}{ DC 2} & Median & 25 & 13.9 & 19.4 & 18.45 & 0.586 & $\mathrm{~T} 0-\mathrm{T} 1=0.288$ \\
\hline & 25 th & 16.6 & 9.57 & 12 & 11.95 & & $\mathrm{~T} 0-\mathrm{T} 2=0.919$ \\
\hline & 75 th & 36.4 & 26.6 & 33.3 & 28.35 & & T0-T3=0.892 \\
\hline
\end{tabular}

${ }^{a}$ T0, basal state; T1, 12 h post-operatively; T2, 24 h post-operatively; T3, 8 days post-operatively. Results of the GEE analysis. ${ }^{b}$ Statistical significance set at 0.017 for Bonferroni correction.
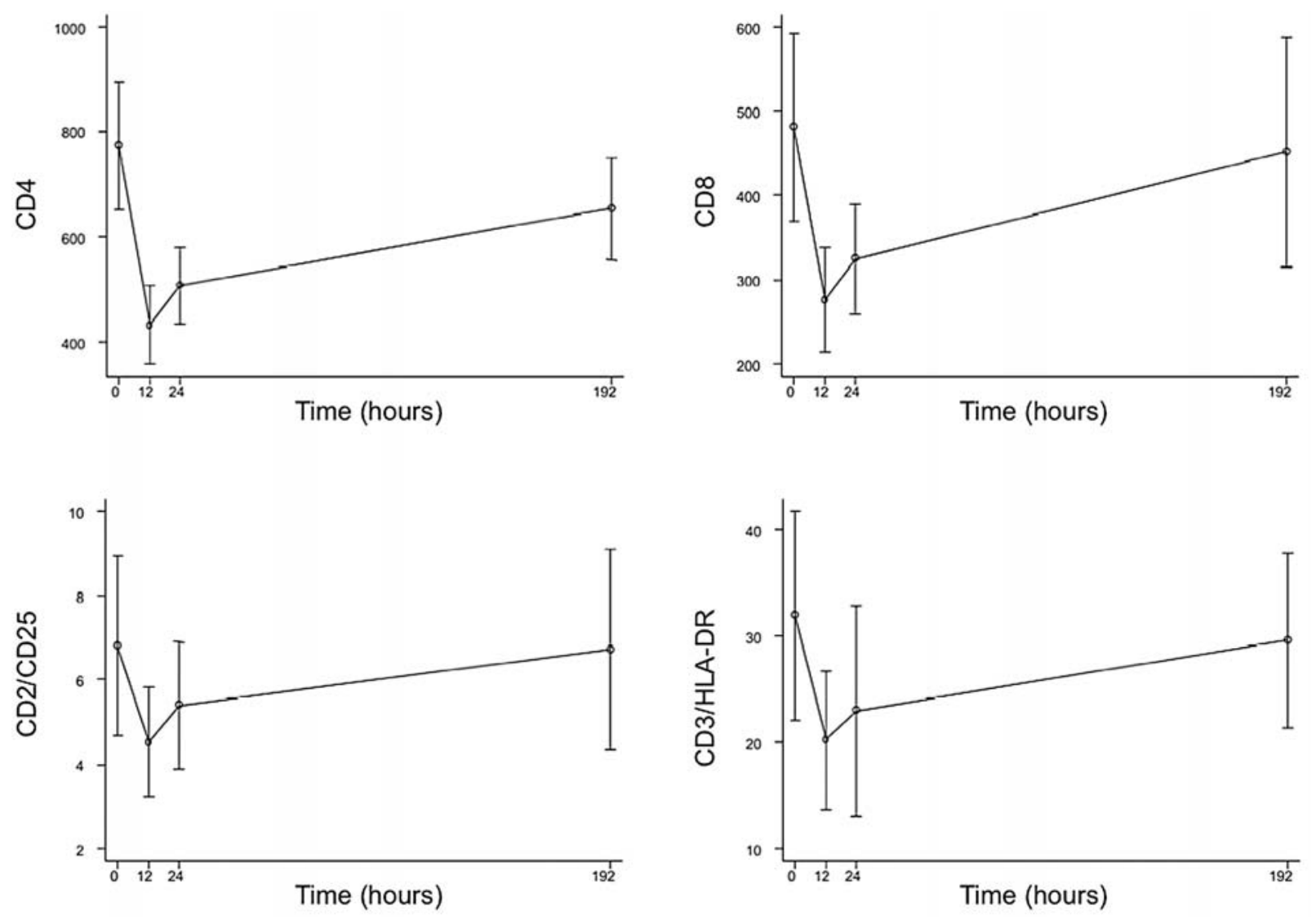

Figure 1. Time changes of selected lymphocyte subsets (CD4, CD8, CD2/CD25, CD3/HLA-DR). Mean and 95\% confidence intervals are shown.

simultaneously, that is all the populations positive for HLA-DR (cocktail+/HLA-DR ${ }^{+}$; dendritic cells were thus identified as cocktail-/HLA-DR ${ }^{+}$.
Three-color analysis allowed identification and counting not only of the total number of circulating dendritic cells but also of DC1 and DC2 subsets. In this case, cells were marked 

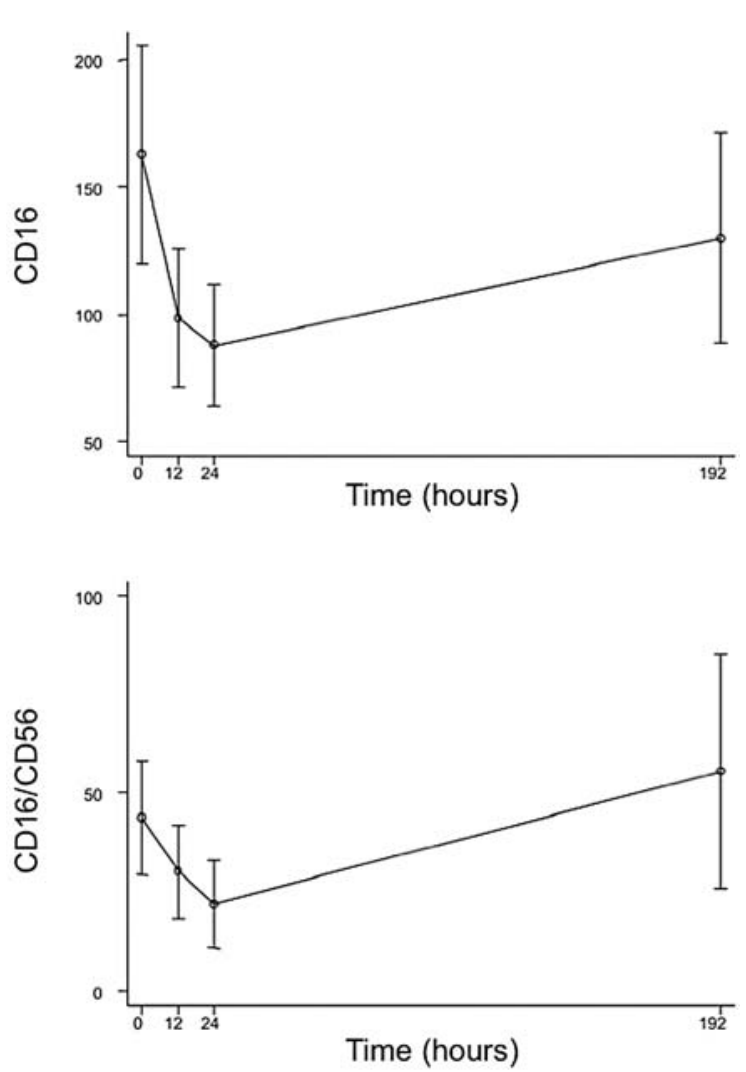

Figure 2. Time changes of two different NK cell subsets (CD16, CD16/ CD56). Mean and 95\% confidence intervals are shown.

with the mixture of FITC, HLA-DR, PC5 and CD11c PE (DC1) or CDw123 PE (DC2). The IgG1 FITC and PE, IgG2a FITC and IgM FITC histotype controls were provided by Coulter Co.

The characteristics of the monoclonal antibodies used for the phenotyping of circulating dendritic cells and their DC1 and DC2 subsets are reported in Table III. The data from the samples were then acquired and saved and 5 parameters were evaluated, 2 on a linear scale, FS and SS, and 3 on a logarithmic scale, FL1, FL2 and FL3.

Cytometric reading was performed using a bitmap on mononuclear cells designed on the cytogram with two physical parameters (FS vs. SS), counting 50,000 events. Applying a gate on dendritic cells (that is cocktail-/HLA-DR ${ }^{+}$cells), the DC1 and DC2 subsets were shown (HLA-DR ${ }^{+} / \mathrm{Leu}_{11 \mathrm{c}^{+}}$and HLA-DR ${ }^{+} / \mathrm{CDw} 123^{+}$, respectively).

The histotype control permitted the differentiation of positive event from negative event areas and to correctly compensate for the three fluorescences.

Statistical analysis. Data were described as median and 25th-75th percentiles or as counts and percent. Mean and $95 \%$ confidence intervals $(95 \% \mathrm{CI})$ at each time point were also computed. For the purpose of the analysis, due to sample size, stage and grade were collapsed into 2 categories ( 0 for stage and grade 1-2; 1 for stage and grade 3-4). Baseline comparisons of subpopulations between categories were performed by means of the Mann-Whitney U test. The association of age and each subpopulation was measured by
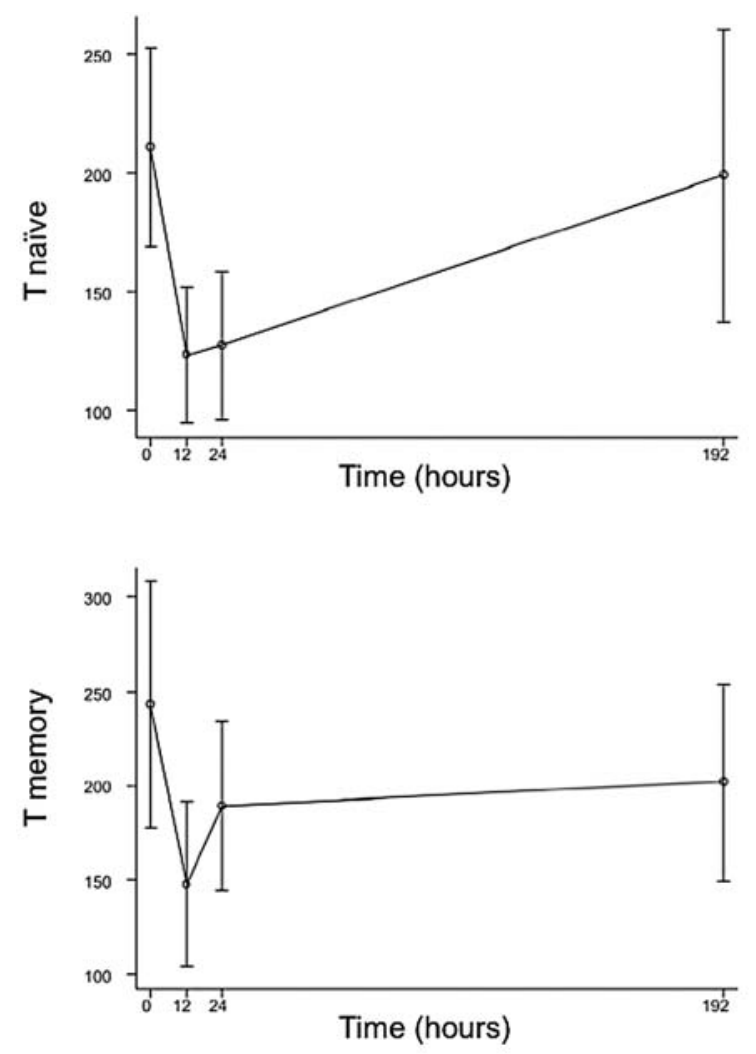

Figure 3. Time changes of selected lymphocyte subsets ( $\mathrm{T}$ naïve, $\mathrm{T}$ memory). Mean and $95 \%$ confidence intervals are shown.

means of the Spearman R. General estimating equations (GEE) were used (to account for intra-patient correlation) in order to evaluate changes over time in the subpopulation levels. Moreover, the interaction of time and type of surgery, stage, grade, presence of metastasis and gender in turn was included into the models to compare subpopulation profiles over time.

Stata 9.2 (StataCorp, College Station, TX, USA) was used for computation. A 2-sided p-value $<0.05$ was considered statistically significant. Bonferroni correction was used for multiple comparisons.

\section{Results}

Lymphocyte subsets and circulating dendritic cells. RCC patients presented a basal (T0) statistically significant activation of CD3/HLA-DR ${ }^{+}$aspecific lymphocytes, of lymphocytes co-expressing the CD4 and CD8 antigens and of the $\mathrm{CD}^{2} 6^{+} \mathrm{NK}$ subset, but the prevalent finding was that of immunosuppression involving naïve T-cells, memory T-cells, CD16 $6^{+} \mathrm{NK}$ and total circulating dendritic cells. The ratio of DC1 to DC2 cells appeared to be preserved in our RCC patients; nevertheless, the absolute number of circulating dendritic cells was significantly lower in cancer patients relative to controls (data not shown) (1).

Changes over time. For most of the analyzed lymphocytic subsets, we observed a significant change in their levels over time, mainly characterized by a marked initial (at T1) decrease, followed by a progressive return to baseline (at T2), with the exception of $\mathrm{CD}_{19}{ }^{+}$(Pan B), dendritic cells and their DC-2 

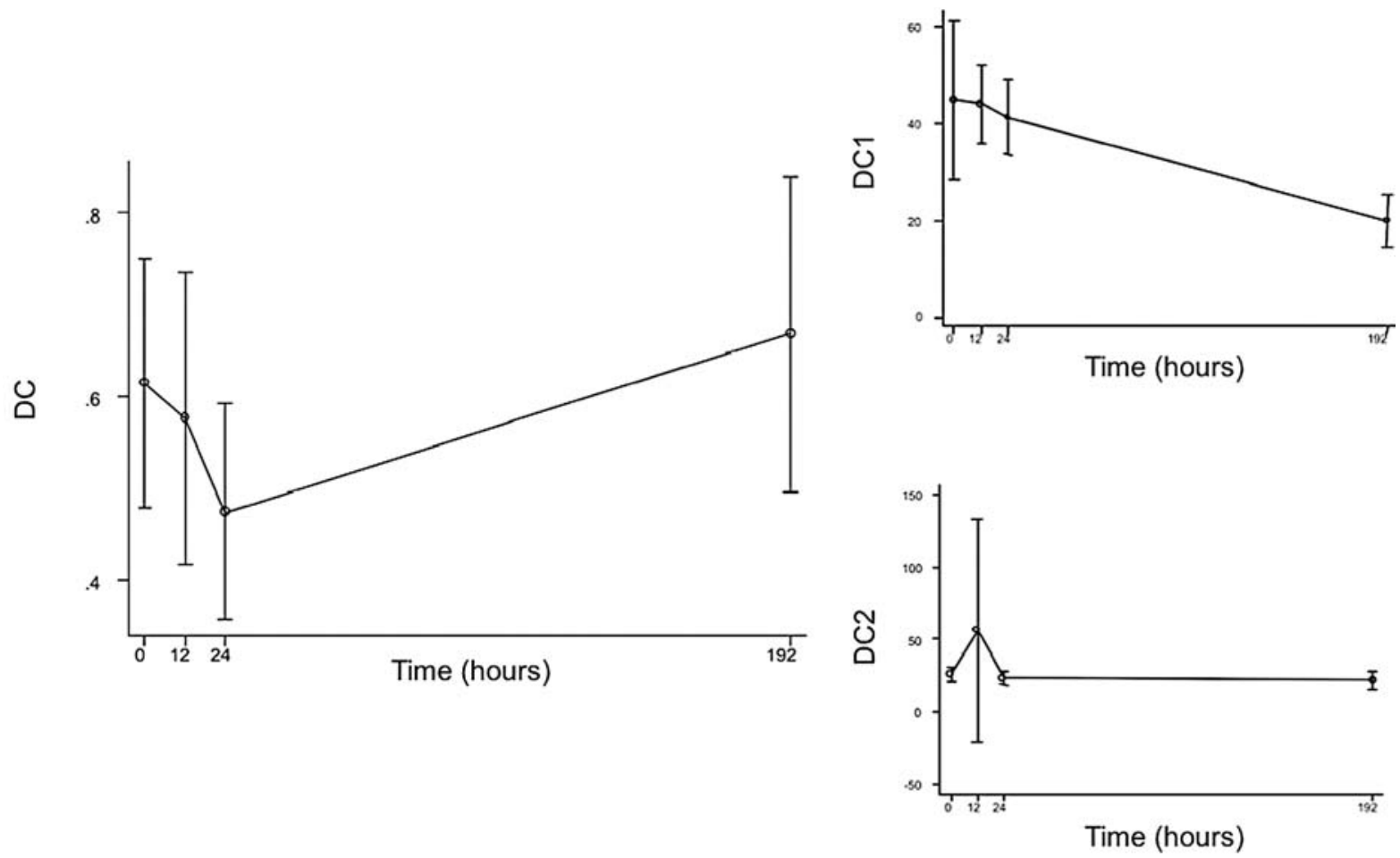

Figure 4. Time changes of DCs and their subsets (DC1, DC2). Mean and 95\% confidence intervals are shown.
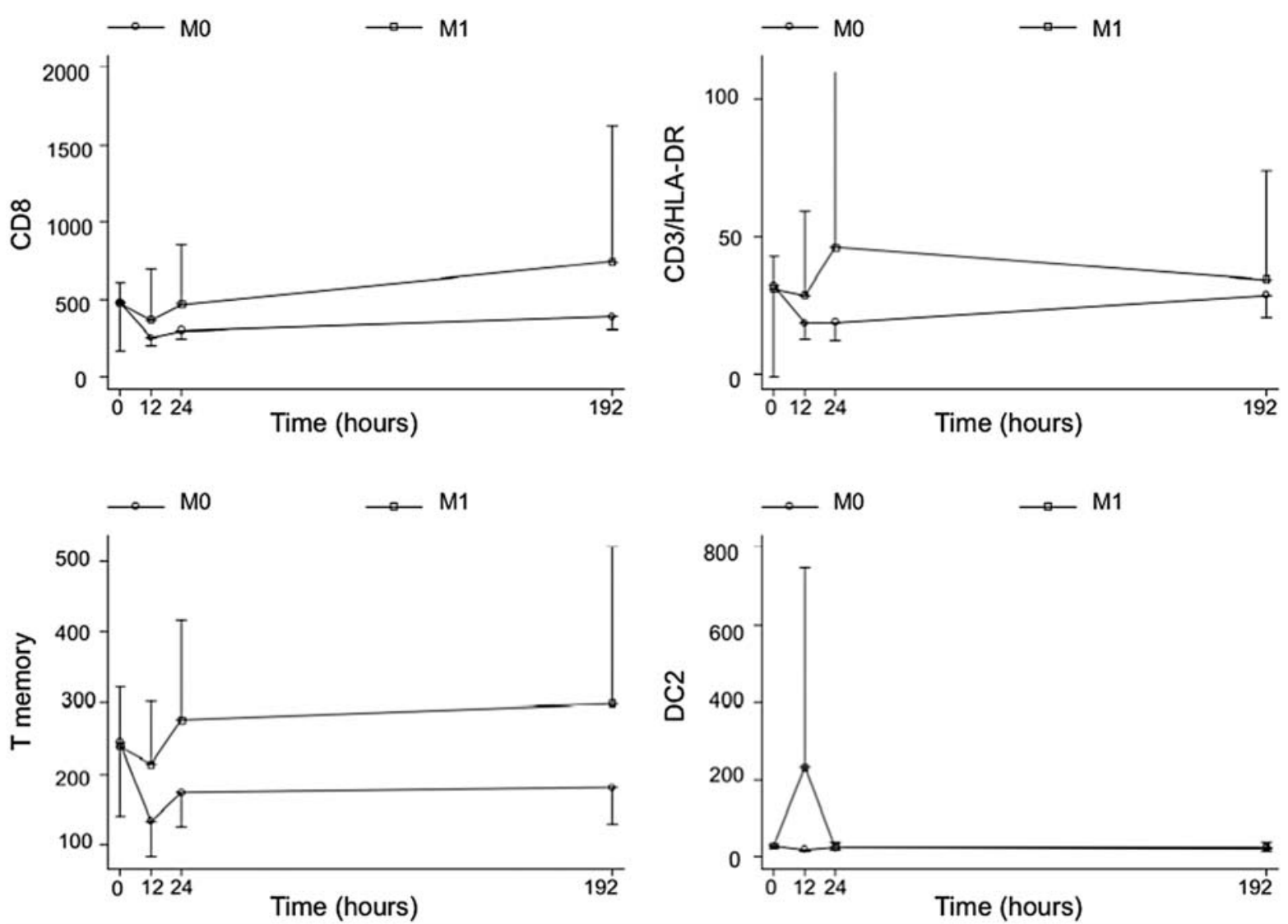

Figure 5. Time changes for CD8, CD3/HLA-DR, CD4/CD45RO T memory and DC 2 according to the presence/absence of metastasis.

subsets, as well as of CD20/CD 38 (early B) and CD4/CD8, $\mathrm{DC}$ and DC2. After 8 days (T3) from surgical removal of tumor, however, there was a return to the basal state, except for
NK cells CD16/ CD56 and DC 1, which continued to present a statistically significant reduction. Overall results are summarized in Table IV and illustrated in Figs. 1-4. 

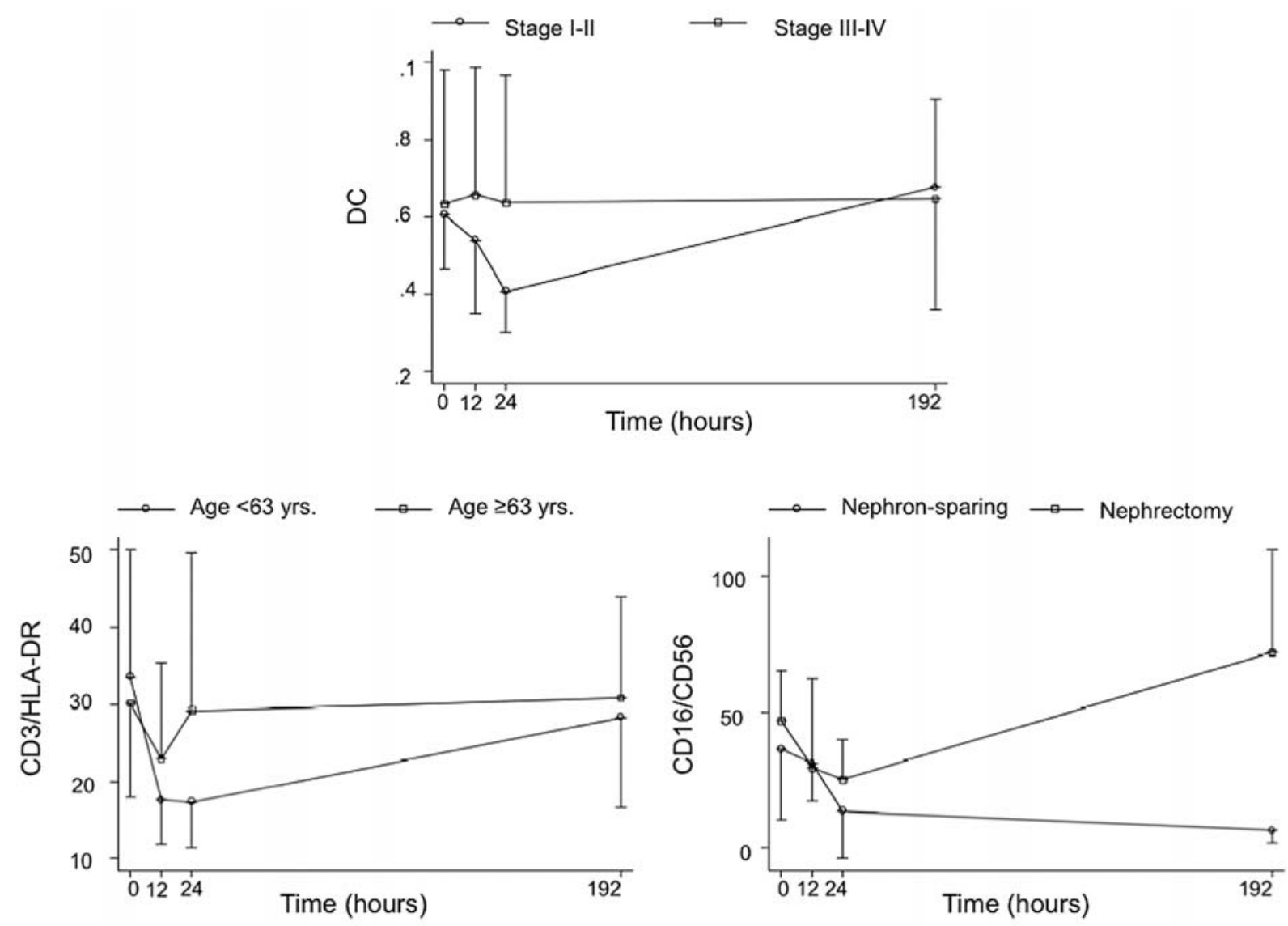

Figure 6. Time changes for CD16/CD56, according to the type of surgery, for DC1, according to stage, and for CD3/HLA-DR, according to age (dichotomized at the median of 63).

Association with patient characteristics. No statistically significant association was found between lymphocyte subset and circulating dendritic cells and any of the following parameters measured at T0: age, gender, disease stage (in terms of TNM), tumor grading or type of surgical approach. However, as shown in Figs. 5 and 6, different time profiles for CD8, CD3/HLA-DR, CD4/CD45RO T memory and DC2 were observed according to the presence/absence of metastasis; for CD16/CD56 according to the type of surgery; for DC1 according to stage; and finally for CD3/HLA-DR according to age (dichotomized at the median of 63).

\section{Discussion}

Renal carcinoma patients, especially (but not only) with metastatic disease, usually exhibit several immunological dysfunctions $(13,14)$. The underlying mechanism for immune dysfunction in cancer patients are probably multifactorial (15); indeed, many factors (advanced age, nutritional status, etc.) contribute to the poorly functioning immune system often observed in neoplastic patients (16). However, the role of the tumor itself was clearly demonstrated years ago in a fibrosarcoma mouse model (17); upon inoculation with tumoral cells, these mice became immune suppressed, as demonstrated by impaired antitumor reactivity of $\mathrm{T}$ cells, associated with decreased expression of signalling molecules. This phenotype was completely reversed following surgical removal of the tumor, unmasking a population of primed $\mathrm{T}$ cells that were capable of rejecting a subsequent tumor challenge.

However, immune suppression, as well as metabolic alterations, are established consequences of surgical stress and trauma, which may expose patients to a higher risk of post-operative complications (18-20). Furthermore, a prospective comparison of the immunological and stress response following either laparoscopic or open surgery for localized RCC clearly showed that both approaches induce similar alterations (21), a result that appears to be in agreement with similar observations done in different tumors $(22,23)$.

In this study, we assessed the evolution (before and after surgery) of immune dysfunctions in patients with RCC undergoing either open radical nephrectomy or nephronsparing surgery.

We confirmed the presence of relevant basal immune defects in RCC patients, a finding that have already been described, both by our group as well as by other researchers $(14,24,25)$; these alterations involved expecially cell-mediated immunity. Immediately after surgical removal of the tumor, we found a transient, but relevant worsening of the above immunosuppression, that touched the majority of the analyzed subpopulations, with the sole exception of pan B, early B, lymphocytes CD4/CD8 and dendritic cells.

It is well known that surgical trauma may induce immunosuppression through imbalance of pro-inflammatory and anti-inflammatory cytokines, as well as a hypoactivity of 
monocytes, which is characterized by a reduced expression of HLA-DR receptor, a defeat of antigen-presenting ability and a reduction in their production of $\mathrm{TNF}^{-} \alpha$ upon stimulation with LPS in vitro (26).

All patients analyzed in this study had returned to immunological basal conditions one week after surgical tumor removal; however, we should keep in mind that the basal status of these patients was already characterized by a profound state of immune suppression (1).

The fact that immune suppression did not completely resolve with the removal of the tumor bulk in those patients that had no metastasis, could have different causes, including the persistence of soluble mediators of immunosuppression (e.g. TGF-ß, gangliosides) despite tumor removal, or alternatively, the persistence of a microscopical residue of neoplastic cells, that could represent a continous source of immunosuppressive molecules. This latter supposition could be supported by the findings reported by several authors, who, using RT-PCR, demonstrated the frequent presence of circulating tumoral cells in radically operated patients.

The lack of significant correlations between clinicopathological features and immunological state, could be explained by the fact that immunosuppression is independent from tumor burden. These findings suggest the possibility that immunostimulatory therapies should be applied in the peri-operative setting with the aim of reducing immunosuppression and, hopefully, also disease recurrence. Prospective studies could thus be warranted in this setting.

\section{References}

1. Porta C, Bonomi L, Lillaz B, et al: Renal cell carcinoma-induced immunosuppression: an immunophenotypic study of lymphocyte subpopulations and circulating dendritic cells. Anticancer Res 21: 165-173, 2007.

2. Kudo D, Rayman P, Horton C, et al: Gangliosides expressed by the renal cell carcinoma cell line SK-RC-45 are involved in tumor-induced apoptosis of T cells. Cancer Res 63: 1676-1683, 2003.

3. Rayman P, Uzzo RG, Kolenko V, et al: Tumor-induced dysfunction in interleukin-2 production and interleukin-2 receptor signaling: a mechanism of immune escape. Cancer $\mathbf{J}$ Sci Am 6 (Suppl 1): 81-87, 2000.

4. Finke JH, Rayman P, George R, et al: Tumor-induced sensitivity to apoptosis in $\mathrm{T}$ cells from patients with renal cell carcinoma: role of nuclear factor-kappaB. Clin Cancer Res 7 (Suppl 3): 940-946, 2001.

5. Ménétrier-Caux C, Bain C, Favrot MC, Duc A and Blay JY: Renal cell carcinoma induces interleukin 10 and prostaglandin E2 production by monocytes. Br J Cancer 79: 119-130, 1999.

6. Mocellin S, Marincola FM and Young HA: Interleukin-10 and the immune response against cancer: a counterpoint. J Leukoc Biol 78: 1043-1051, 2005.

7. Mickisch GH, Garin A, van Poppel H, et al: Radical nephrectomy plus interferon-alfa-based immunotherapy compared with interferon-alfa alone in metastatic renal-cell carcinoma: a randomised trial. Lancet 358: 966-970, 2001.
8. Flanigan RC, Salmon SE, Blumenstein BA, et al: Nephrectomy followed by interferon alfa- $2 b$ compared with interferon alfa- $2 b$ alone for metastatic renal-cell cancer. N Engl J Med 345: $1655-1659,2001$

9. Danna EA, Sinha P, Gilbert M, Clements VK, Pulaski BA and Ostrand-Rosenberg S: Surgical removal of primary tumor reverses tumor-induced immunosuppression despite the presence of metastatic disease. Cancer Res 64: 2205-2211, 2004.

10. Mullen CA, Rowley DA and Schreiber H: Highly immunogenic regressor tumor cells can prevent development of postsurgical tumor immunity. Cell Immunol 119: 101-113, 1989.

11. Almand B, Clark JI, Nikitina E, et al: Increased production of immature myeloid cells in cancer patients: a mechanism of immunosuppression in cancer. J Immunol 166: 678-689, 2001.

12. Barbieri C, Fujisawa MM, Yasuda CL, et al: Effect of surgical treatment on the cellular immune response of gastric cancer patients. Braz J Med Biol Res 36: 339-345, 2003.

13. Uzzo RG, Rayman P, Novick AC, Bukovski RM and Finle JH: Molecular mechanisms of immune dysfunction in renal cell carcinoma. In: Renal Cell Carcinoma: Molecular Biology, Immunology and Clinical Management. Bukowski RM and Novick AC (eds). Humana Press, Totowa, NJ, pp63-78, 2000.

14. Bohm M, Ittenson A, Philipp C, Rohl FW, Ansorge S and Allhof EP: Complex perioperative immuno-dysfunction in patients with renal cell carcinoma. J Urol 166: 831-836, 2001.

15. Malmberg KJ: Effective immunotherapy against cancer. A question of overcaming immune suppression and immune escape? Cancer Immunol Immunother 53: 879-892, 2004.

16. Pawelec G, Barnett Y, Forsey R, et al: T cells and aging, January 2002 update. Front Biosci 7: 1056-1183, 2002.

17. Salvadori S, Martinelli G and Zier K: Resection of solid tumor reverses $\mathrm{T}$ cell defects and restores protective immunity. J Immunol 164: 2214-2220, 2000.

18. Biffl WL, Moore EE, Moore FA and Peterson VM: Interleukin-6 in the injured patient. Marker of injury or mediator of inflammation? Ann Surg 224: 647-664, 1996.

19. Weissman C: The metabolic response to stress: an overview and update. Anesthesiology 73: 308-327, 1990.

20. Hershman MJ, Cheadle WG, Wellhausen SR, Davidson PF and Polk HC Jr: Monocyte HLA-DR expression characterizes clinical outcome in the trauma patient. Br J Surg 77: 204-207, 1990.

21. Landman J, Olweny E, Sundaram C, Chen C, Rehman J, Lee D, Shalhav A, Portis A, McDougall E and Clayman R: Prospective comparison of the immunological and stress response following laparoscopic and open surgery for localized renal cell carcinoma J Urol 171: 1456-1460, 2004.

22. Tang CL, Eu KW, Tai BC, Soh JG, MacHin D and Seow-Choen F: Randomized clinical trial of the effect of open versus laparoscopically assisted colectomy on systemic immunity in patients with colorectal cancer. Br J Surg 88: 801-807, 2001.

23. Leung KL, Lai PB, Ho RL, Meng WC, Yiu RK, Lee JF, et al: Systemic cytokine response after laparoscopic assisted resection of rectosigmoid carcinoma. A prospective randomized trial. Ann Surg 231: 506-511, 2000.

24. Robson CJ, Churchill BM and Anderson W: The results of radical nephrectomy for renal cell carcinoma. J Urol 101: 297-301, 1969.

25. Dadian G, Riches PG, Henderson DC, Taylor A, Moore J, Atkinson $\mathrm{H}$, et al: Immunological parameters in peripheral blood of patients with renal cell carcinoma before and after nephrectomy. Br J Urol 74: 15-22, 1994.

26. Menger MD and Vollmar B: Surgical trauma: hyperinflammation versus immunosuppression? Langenbecks Arch Surg 389: 475-484, 2004. 